\title{
COVID-19 and Bangladesh: Socio-Economic Analysis towards the Future Correspondence
}

\author{
1. Momotaj Begum, Lecturer, Dept. of Agricultural Marketing and Business \\ Management, Sylhet Agricultural University, Sylhet. \\ E-mail: momotaj.ambm@sau.ac.bd \\ 2. Md. Shaikh Farid, Assistant Professor, Dept. of Agricultural Marketing and \\ Business Management, Sylhet Agricultural University, Sylhet. \\ E-mail: farid.ambm@sau.ac.bd \\ 3. Swarup Barua, Assistant Professor, Dept. of Agricultural Marketing and Business \\ Management, Sylhet Agricultural University, Sylhet. \\ E-mail: sbarua.ambm@sau.ac.bd \\ 4. Dr. Mohammad Jahangir Alam, Professor, Dept. of Agribusiness and Marketing, \\ Bangladesh Agricultural University, Mymensingh \\ E-mail: alambau2003@yahoo.com
}

\begin{abstract}
The COVID-19 has caused gigantic negative effects on populace wellbeing, society, education, and the economy in Bangladesh. The aim is to deliver a comprehensive overview of the observed and the possible impacts that could appear in the coming days. The study is based on secondary information. During the early period, due to a lack of accurate facts about the case affected and death tension up-and-down among the nations. The total number of confirmed cases is increasing following geometric patterns in Bangladesh. Dairy farmers, vegetable producers, pharmaceuticals, poultry farmers are in deep crisis due to lower prices. Also, the pandemic has seriously affected educational systems, banking, FDI, ready-made garments, remittances, etc Finally, it is not possible to mitigate the effects of pandemic individually but the integrated effort from the state authority as well as concern people of all sectors need to come forward.
\end{abstract}

Key words: COVID-19, Socio-Economic, Impact, Bangladesh 


\section{Introduction}

Newly emerging SARS virus is not the first time emerges to the world; it belongs to the family of coronavirus. Although these viruses are common in animal but some of them are affect human being [WHOa (2020), Adhikari et.al. (2020)]. However, a new strain of the coronavirus family emerged in Wuhan (Hubei provinces) of China in December 2019 which infected thousands of people of the globe. The World Health Organization (WHO) named the virus as 2019 novel coronavirus and present reference name for the virus is severe acute respiratory syndrome coronavirus 2 (SARS-CoV-2). This virus affected lower respiratory tract of patients with pneumonia [Uddin et. al. (2020)]. The outbreak began from a wholesale market of Wuhan where workers slaughtered animal like dog, pig, rat, cat, civet and snakes etc. [Chen \& Hong (2020)]. Although novel coronavirus was first traced in Wuhan, China, in December 2019 the number of affected people is gradually enhanced within a month and spreading in Italy, USA, France, Iran and Thailand, South Korea, Japan and many more which is knocking the world for experiencing such outbreak[Uddin et. al. (2020)]. Therefore this outbreak is considered as a Public Health Emergency of International Concern and recognized as a pandemic by the World Health Organization on 11 March 2020 [WHOb (2020), WHOc (2020)]. The virus is transmitted by close contact that is defined as 1 metres ( 3 feet) by WHO and 2 metres ( 6 feet) by Centre for Disease Control and Prevention (CDC) [ CDCa (2020), $\mathrm{WHO}_{\mathrm{b}}$ (2020)] and by small droplets produced during sneezing, coughing even talking [WHOd (2020), European Centre for Disease Prevention and Control (2020)]. People may also be affected by this virus by touching a contaminated surface and then without washing their hand touching their face [CDCc (2020), WHOd (2020)]. WHO recommended some preventive measure which includes washing hand through water and soap often for at-least 20 seconds, avoiding touching the eyes, mouths or nose with unwashed hands, practicing good respiratory hygiene, staying at home, avoiding crowded place, maintaining social distance, covering ones mouth when coughing and sneezing, selfisolated himself if someone suspected himself that he might be affected [CDCa (2020), CDCb (2020), WHOe (2020)]. On April 4, 2020, about 1469223 coronavirus infected people have been identified in more than 200 countries including Bangladesh [www.worldometers.info.] where almost 316482 people have recovered and more than 86256 deaths have been reported. [CSSE (2020)]. 
On March 8, 2020, a coronavirus pandemic was first confirmed in Bangladesh by The Institute of Epidemiology, Disease Control and Research (IEDCR) [IEDCR (2020)]. To stop the spread of this virus, there are lots of actions taken by the government of the affected countries like regional or national quarantine throughout the country and the world, travel restriction, Hazard control in workplace, cancellation and postponements of events, curfews, boarder enclosure and screening at airports and train station etc. These kinds of preventive measures like lockdown the borders may hinder the normal flow of raw materials, products and services, capitals, humans which resulting in business and production shutdowns at least temporarily [Barua (2020)].This pandemic has led to acute global socioeconomic disruption such as extensive fear of supply shortage resulting panic buying. According to UNESCO, nationwide or local basis about 188 countries closed schools, college and universities which affecting more or less $90 \%$ of the world's students [UNESCO (2020),https://en.unesco.org/]. All major economies like G7 countries who jointly share $65 \%$ of the manufacturing of the world, $60 \%$ of world's demand and supply (GDP), and $41 \%$ of world exports have been heavily affected by these pandemic and other countries will follow these [Baldwin and Mauro (2020)]. Mauro B.W. (2020) termed such outcomes as 'macroeconomic flu' - a temporary negative demand and supply Shock - causing fall of output temporarily, followed by recovery quickly and possibility of full catch-up on the shortfall. But that happens when it is a normal flu not like COVID-19 outbreak which is seemingly producing large scale, global, and possibly persistent economic disruption [Mauro (2020)]. To prevent the outbreak of coronavirus, the Government of Bangladesh also declared ten day shut-down on 22 March which is effective from 26 March to 4 April [Dhaka Tribune (2020)] later the shut-down is increased to 10 April 2020. As of 4 April 2020, the Government of Bangladesh has confirmed testing 2086 samples among which there are a total of 70 confirmed cases, 30 recoveries, and 8 deaths in the country [IEDCR (2020)]. As doing so, the economy of Bangladesh is under threat. There are so many papers have been published among most of them studied epidemiological, demographic, and clinical issues of the virus and its outbreak. Very few studied about the world economy but it is essential to identify the economic impact of coronavirus pandemic. This paper attempts to identify the current and future likely economic implications of the coronavirus pandemic in Bangladesh.

\section{Materials and methods}


This paper cannot produce any quantitative estimate of the future as it is too early stage of outbreak of coronavirus in Bangladesh. Therefore it aims to deliver a comprehensive and indicative overview on the observed and the possible impacts that could emerge in the coming days. The study isdesigned on the basis of secondary information. As we are in the initial stage of coronavirus outbreak the available information is limited and it is difficult to find publications that only show how the coronavirus outbreak impacts the economy of Bangladesh. To have a better understanding, we collected the information from materials published so far by different media outlets, think tanks, research agencies, policy experts and newspapers. Besides this, the internet has been used as another source of information. The main attempt of this study is to summarize the literature about pandemic and its socio-economic impact on Bangladesh economy.

\section{Result and Discussion}

Social Impacts: Qiu et. al. (2018) studied that the SARS outbreak in 2013 in China had a large impact on society of China. Social panic waved in the society because of a lack of faithful official information, and spread of rumors [Qiu et. al. (2018)]. Recent outbreak of COVID-19 is also creating panic not only in China but the whole globe as it is a pandemic. Covid-19 also caused a very severe impact on society, particularly in Bangladesh. During the early period of the Covid-19 outbreak, panic surged in the society. Since lack trustful and official information about the case affected and death, people started to believe the rumors which are spread through social media, mobile phone, word of mouth and many other ways. Experts criticized that not enough tests were conducted in the country that has a population of over 160 million [Dhaka Tribune and news.yahoo.com.30 March, 2020]. Newspaper reports and social media continued to report about additional deaths of patients with COVID-19 symptoms. Some of the deceased were treated at COVID-19 isolation centers at hospitals in the districts and others were denied treatment, though no tests were conducted to confirm contagion [New Age, 30 March 2020]. Since prevention measures of Covid-19 are wearing a mask, washing hands through soap or sanitizer surprisingly the worth of the hand sanitizer and mask were high by the unethical businessman. On the other hand this pandemic also impact on religion by cancellation of the prayers in mosque, temple and churches of many affected countries. Worship through live stream is offered by many churches and temples [Parke (2020)]. Similarly in Bangladesh religious mass gathering are discouraged by the government. Most of the people of in Bangladesh are Muslim 
and the rural religious scholars protest against this government declaration and people started to gather in mosque and pray for recovery from this virus. This large togetherness of religious people pose a threat for Bangladesh [Rafee (2020)]. Not only that the price level also increased dramatically. Since people were panicking about this outbreak and the government of Bangladesh has taken initiatives of lockdown people started to purchase daily necessary abnormally which is the main reason for raising the price of the essential commodities. Prices of hand sanitizers and face masks have increased abnormally. Without giving any explanation retailers hiked the price of masks up to $400 \%$. Though masks were available at high prices on footpaths, most of the drug store was found to be out of stock of masks and sanitizer after the announcement of detecting coronavirus in three persons in the country [Irani (2020)].

Economic impact: The COVID-19 outbreak has already started to affect different sectors of economy. Firstly the immediate impact of the pandemic is temporary shutdown of factories and businesses in an affected country; as a result production is declined [Barua (2020)]. For example, productions in China and some other countries have already been temporarily suspended by many large multinational companies, and transport routes through air and sea to and from China and many other economies have already been closed down, resulting in a partial or full border locked down[Whalen \& Bhattarai (2020), Wilson (2020)]. Barua, S. (2020) studied that the pandemic could affect international relationships by affecting the existing and the upcoming economic programs under government to government $(\mathrm{G} 2 \mathrm{G})$ cooperation particularly between China and other economies [Barua (2020)]. Due to the outbreaks, China backed public projects under investment or aid frameworks have come to halt - as materials and project staff cannot travel back and forth resulting delays or cancellation of $\mathrm{G} 2 \mathrm{G}$ aid or investment programs as China and their partner countries. Currently, China has about 7000 projects underway in 69 countries under the G2G cooperation framework, which could have a big hit due to this pandemic [Barua, (2020)]. In Bangladesh, Major undertakings like Padma Bridge, Padma Rail Link, Karnaphuli Road Tunnel and the Greater Dhaka Sustainable Urban Transport Project include monetary and specialized contribution from China, the two of which are required to be antagonistically influenced. Beside these, the three prominent sectors of the economy of Bangladesh that are Agriculture, Industry and service sectors which contributed 18\%, 29\% and $53 \%$ to the GDP of the country respectively are adversely affected by the coronavirus pandemic 
[BER-2019]. The Asian Development Bank (2020) predicts that Bangladesh will lose roughly \$3 billion in its GDP simultaneously work cuts for around 9 million individuals. In particular, in the sectoral situations, the most noteworthy GDP misfortune and employment cuts will be good to go division including money related area, exchange and open administrations by $\$ 1.14$ billion and 2,01,106 individuals separately followed by agribusiness ( $\$ 637$ million, 4,58,000 individuals), the travel industry (\$510 million, 50,000 people), development and utilities (\$400 million, 1.18 million people) and transport administration (\$334 million, 67,000 people) [ADP (2020)].

Agriculture Sector: Gatiso et. al. (2018) uncovered that farming creation had diminished during the EVD pestilence, contrasted with their earlier year's creation (i.e., before the episode). This decrease underway could be because of a lessening in the size of cultivable ranches activated by the end of business sectors and absence of go betweens who buy rural items from ranch entryways and transport them to the market places. In Bangladesh dairy farmers have sought immediate support from the government as they cannot sell milk due to the countrywide lockdown in the aftermath of the new coronavirus. Everyday around 12 to 15 million litres of milk remain unsold across the country, which caused Tk 570 million in daily losses to the marginal dairy farmers. Bangladesh currently produces 9.9 million tonnes of milk annually, which is $70 \%$ of the total national demand. But about 12 to 15 million litres of milk have remained unsold for lockdown. The country's dairy farmers are in deep crisis because they are forced to sell milk at $\mathrm{Tk} 10$ to Tk 12 a litre somewhere in the country while in other areas they cannot sell at all [Roy (2020)]. On other hand Bangladesh's fares make up over 70\% of the crabs in the Chinese market. China quit bringing in crabs this year in an offer to stem the episode of another covid-19 (http://www.theindependentbd.com/post/237519). In April 2013, the H7N9 avian flu scourge caused the value list of meat and poultry and their items to tumble to 101.5 on a year-on-year premise. Because of the episode, China's poultry industry endured lost more than RMB 40 billion. Simultaneously, customers' trust in poultry items declined, which had a significant impact on meat and poultry costs [Qiu et. al. (2018)]. Thus Bangladesh Poultry Industries Central Council (BPICC) said that the offer of poultry chicken and eggs has dropped in the market because of shutdown which has caused destruction on the poultry business. BPICC as of now anticipated their misfortune will be between Tk1, 150 crore, and Tk 1,650 crore 
[https://tbsnews.net/economy/industry/poultry-sector-stares-over-tk1150-crore-losses-63472]. In the case of vegetables it is assumed that due to the outbreak of Covid-19 Bangladesh will lose $\$ 20$ million export earnings.

Industrial Sector: The Covid-19 pandemic has had a profound impact on the supply chain and demand for the apparel sector because of challenges of raw material source and cancelled orders. According to the country's commerce minister "More than $\$ 2.6$ billion worth of orders in Bangladesh's garment sector has been withdrawn and new cancellations are coming up" Choudhury S. R. (2020) [https://www.cnbc.com/2020/03/27/coronavirus-bangladesh-garmentsector-faces-growing-order-cancellations.html] revealed Bangladesh piece of clothing manufacturing plants are probably going to battle to pay some 4.1 million laborers in the area, who are low workers. BGMEA's site appeared about $\$ 2.67$ billion worth of requests - or 828 million bits of attire in 966 manufacturing plants - have just been dropped or suspended, and it influences around 1.96 million specialists so far. On the other hand global production of Cotton is largely dominated by India, China, the US, Pakistan, and Brazil. As demand of cotton in China is declined for their long time lockdown due to coronavirus pandemic that resulting demandsupply mismatch in international market. Along with this, decrease in yarn exports for India to China will mean an even greater excess supply of yarn and lower prices in the international market.[Lightcastle analytics wing https://www.lightcastlebd.com/insights/2020/03/29/the-effect-of-covid-19-on-bangladeshsapparel-industry]. 
Figure 1: Partner country's share of Cotton import by Bangladesh

\section{(Partner countrys share of Cotton import by quantity \%)}

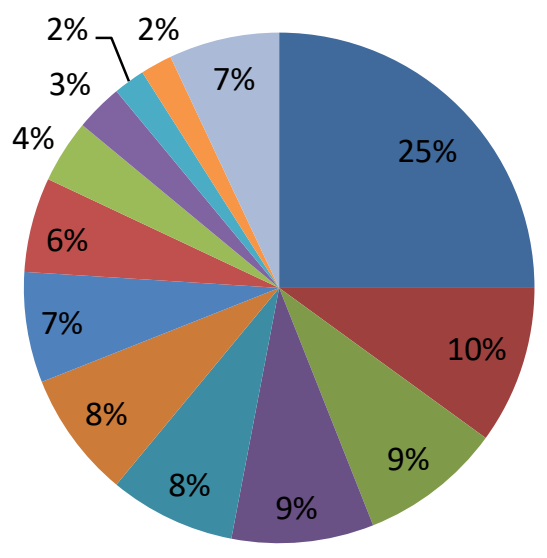

- Indian

- USA

- Australia

- Mali

- Burkania Faso

- Benin

- Brazil

- Uzbek

- Turkmen

- Cameroon

Source: Author, Based on the data generated from Bangladesh Bank-2020.

Crude cotton in the Gondal (Gujarat) showcase shed right around 10 percent to exchange at Rs 4,280 a quintal in the main seven day stretch of March from a degree of Rs 4,755 per month prior. Cotton yarn lost 2-3 percent in the course of the most recent one month, while engineered yarn declined by 4-5 percent during the previous one month, following a fall in unrefined costs [Jha and Narasimhan (2020)]. Since India is the largest importer of cotton of Bangladesh falling price of cotton in the international market may affect the cotton industry of Bangladesh.

Similarly, the pharmaceutical industry is affected as Active Pharmaceutical Ingredients (APIs), which is raw materials for the pharmaceutical sector, is import dependent. About $95 \%$ of all APIs worth Tk 5,000 crore is imported annually from abroad, the largest quantity from China, followed by South Korea and India. Since it is an import dependent industry so it will face hard times. On the other hand, the COVID-19 outbreak is expected to lead to higher demand of sanitizing chemicals, and other medications in the short-term to seek prevention and basic treatment measures [Nazrul S. (2020)].

Service Sector: Among the Economic Sectors in Bangladesh, Service segment is generally significant. The commitment of administration division to the GDP is about $53 \%$ (Bangladesh Economic Review-2019). In this way, Service divisions impact the improvement of national 
economy. There is an idle interest for administrations in Bangladesh. To indicate the need of administrations for gigantic populace of Bangladesh, such areas are to be opened for private business people with required control. The gigantic commitment of administration part and an expanding pattern in that have assumed a significant job in high development of GDP. Due to Covid-19 pandemic, service sector might be hampered badly. The implications are discussed.

Health Effects: One of the first sectors impacted by an outbreak is the public and private system. The most crucial aspect of an epidemic or pandemic is, and will always remain, human suffering and the loss of lives. When tainted by COVID-19, it can cause fever, hack, breathing issues, and in serious cases pneumonia and extreme intense respiratory disorder, cardiovascular breakdown and consequent passing [Barua, S. (2020)]. The numbers of infected cases and death globally are increasing so rapidly. As of 5 April 2020, the number of infected cases globally stands at 12, 04,782, with 64,849 death cases [www.worldometers.info].

Figure: 2. Country wise total number of infection and death caused by COVID-19

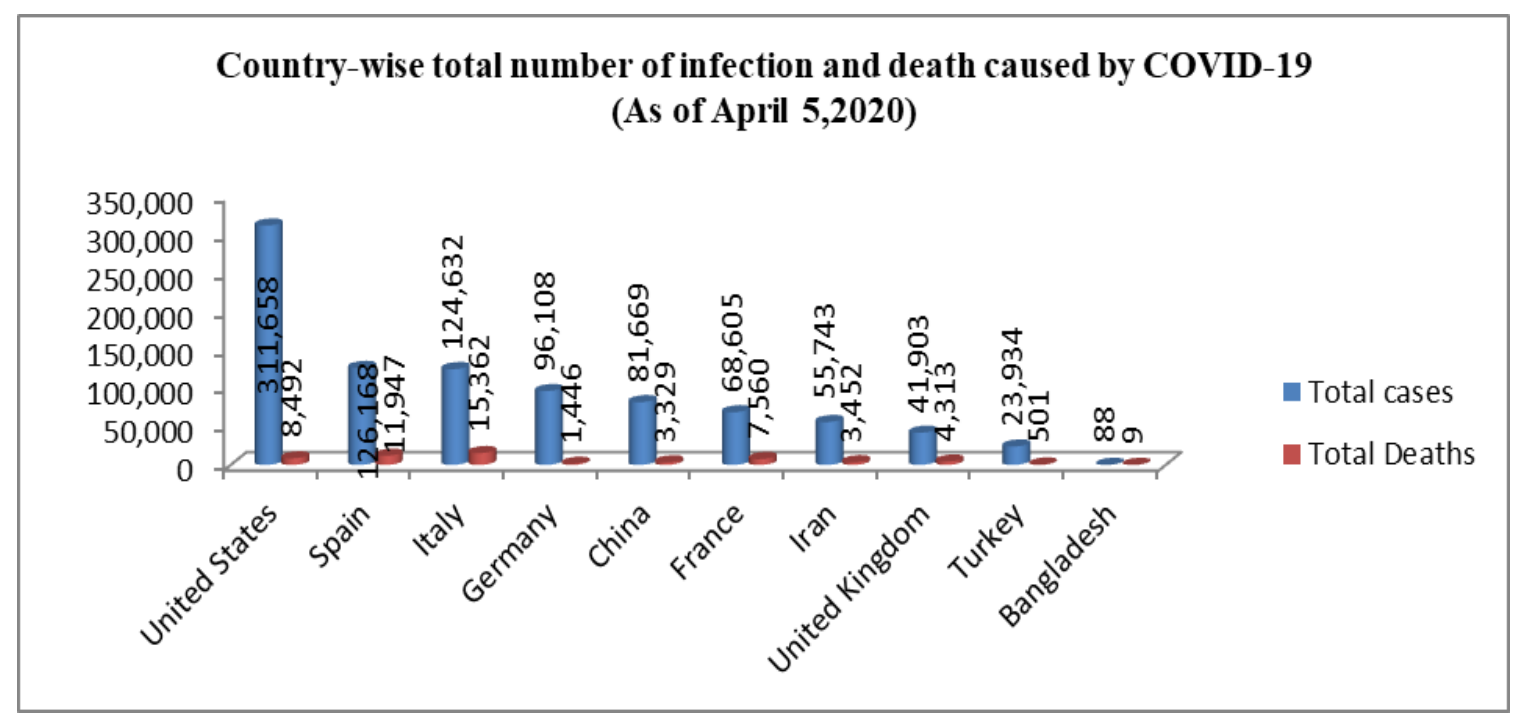

Source: Author, Based on the data as of 5 April, 2020 from www.worldometers.info

The number is stunningly high when compared to other similar epidemics in the past; for example, the SARS outbreak in China in 2003 affected more than 8000 individuals with over 700 deaths from 1 November, 2002 to 31 July, 2003 [Qiu, W. (2018)]. While the virus has already spread across 200 countries and territories, the most affected countries are the US, Spain, Italy, Germany, China, and France showed in figure 2. Although coronavirus cases are much 
lower in Bangladesh compared to the USA, Italy, France and China surprisingly Bangladesh is in third highest position in case of death rate that is $10.22 \%$ and first and second position belongs to Italy $(12.32 \%)$ and France (11.02\%). Higher death rate indicates that coronavirus pandemic affects the health sector of Bangladesh adversely and needs more support.

Although it sounds that the number of infected and death case is much lower compared to other countries like USA, Spain, Italy, France and China but if we show the figure 3 and 4 which depicts the daily information about coronavirus case of mostly affected countries like China. It provides a clear indication that the gradual rise of infected case is between 4-5 weeks later. If we show the figure 4 in the case of Bangladesh which depicts that after $5^{\text {th }}$ weeks there are 88 cases are reported. It seems Bangladesh is in a crucial stage and it may be transmitted and effected more cases.

\section{Figure 3. Total confirmed cases and total deaths in China}

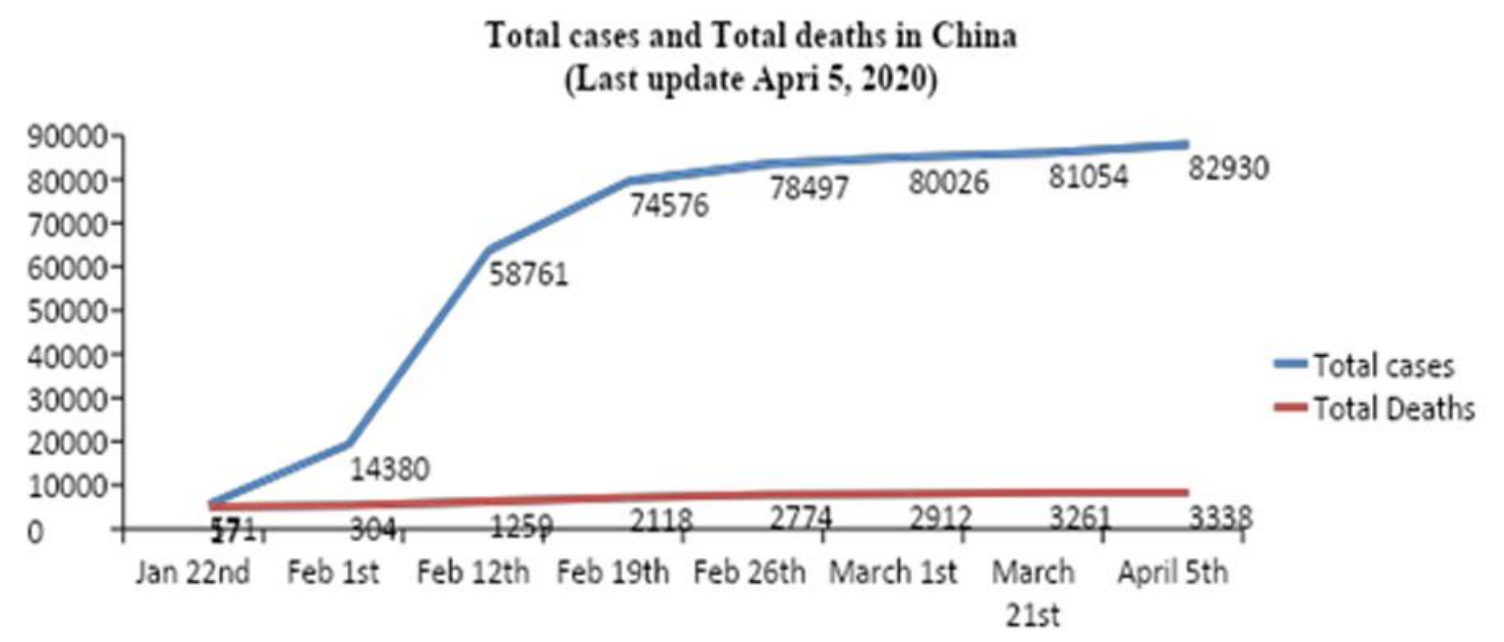

Source: China National Health Commission, 2020 
Figure 4. Total confirmed cases and total deaths in Bangladesh

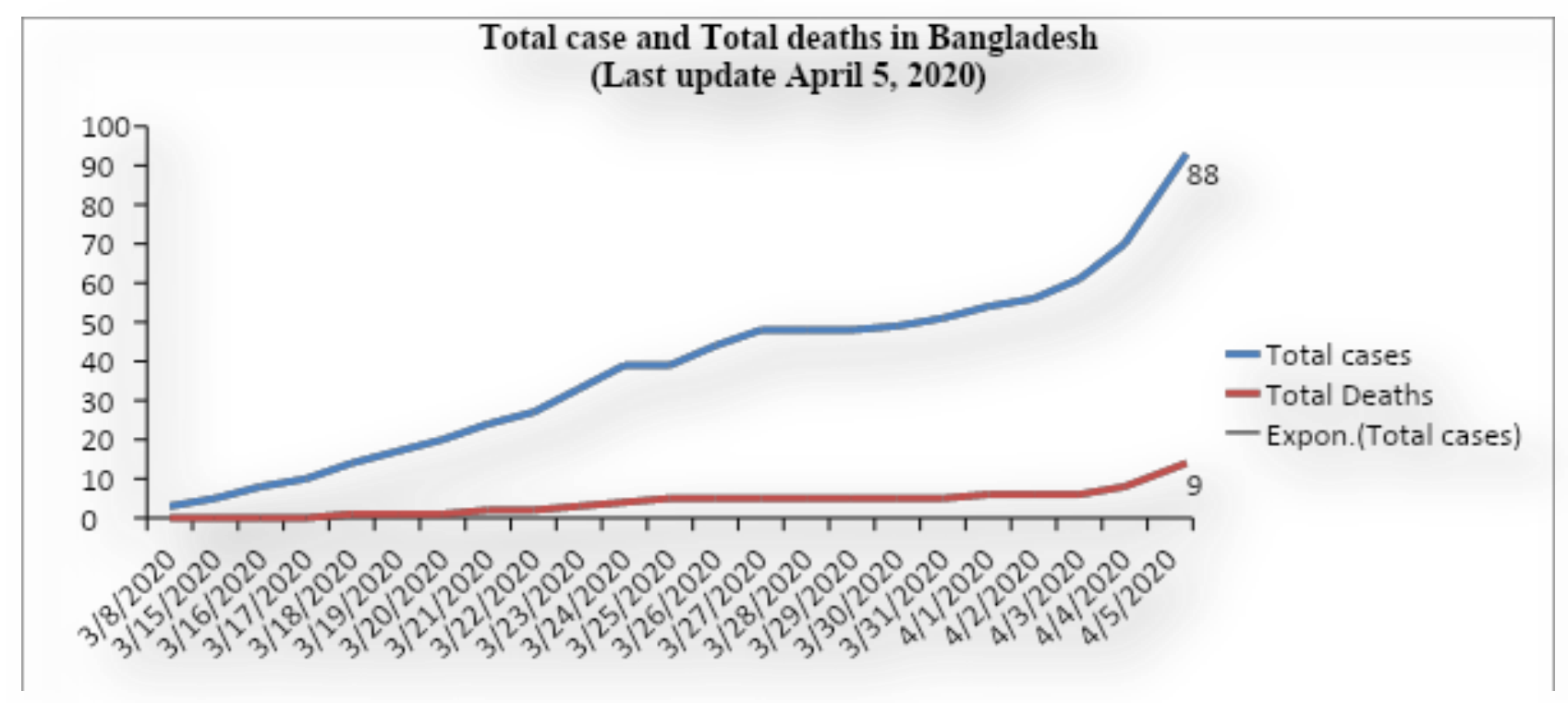

Source: Author, Based on the data from IEDCR as of 5 April, 2020

We have entered the crucial fifth week since the coronavirus was first detected in Bangladesh and the rate of infection curve has started to move up sharply as was predicted from the experiences of the other pandemic affected countries. The very low numbers of testing of suspected patients are still not producing the real picture of the situation but it is clear, as the number of tests increases so does the number of newly detected patients. Ironically the infection pattern in Bangladesh is not similar like other countries. Clearly it is not following the epidemiological trend and prediction. In plain language, science cannot explain the COVID-19 in Bangladesh.

The Government of Bangladesh has set up and fortified its national and neighborhood observation frameworks to forestall and control ailments and has additionally extended its research center limit. Then again the mental effect of Covid-19 was additionally intense. The trouble was progressively unmistakable among the gatherings of specialists and medical caretakers who were working with patients. Bangladesh stays at high danger of the coronavirus spread as authorities said that Bangladesh's network with the nations where standard rates of the 
novel infection happened left it with the possibility of infection contamination whenever. According to the Institute of Epidemiology, Disease Control and Research (IEDCR) director Meerjady Sabrina Flora:

\section{'We are at high risk of the coronavirus spread which has compelled us to urgently act to take preventive measures against the spread of the highly contagious novel virus'}

Educational impact: Most governments around the globe have incidentally shut instructive organizations trying to contain the spread of the COVID-19 pandemic. As per information discharged by UNESCO on 5 April, 2020 school and college terminations due to COVID-19 were actualized across the nation in 188 nations including restricted terminations, this effects over 1.5 billion understudies around the world, representing $91.3 \%$ of enlisted learners [UNESCO, https://en.unesco.org/]. The pandemic has influenced instructive frameworks in Bangladesh likewise, prompting the across the board terminations of schools and colleges.

Figure 5: Total Affected Learners on 5 April, 2020

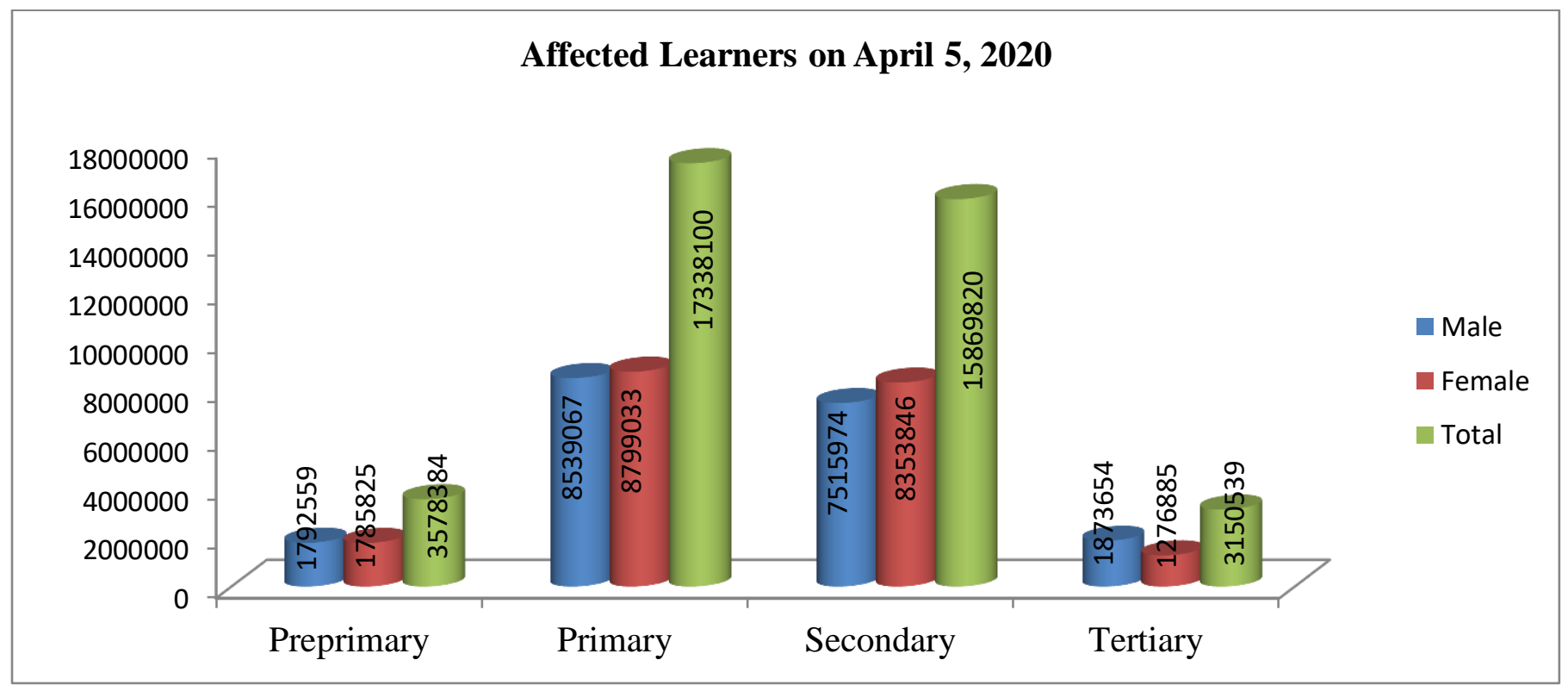

Source: Author, based on the data from UNESCO as of 5 April, 2020

On 16 March 2020, Education minister declared the early vacation of all educational institutions (schools, colleges and Universities) for the next April 04, 2020 but the time was extended to April 11, 2020 due to increase the number of infected people (MOE-2020) Figure 5 depicts how 
the coronavirus affects the educational sector of Bangladesh. There are about 39,936,843 learners are affected among which 3,578,384 are pre-primary learners, 17,338,100 are primary learners, secondary and tertiary learners are 15,869,820 and 3,150,539 respectively. Figure 5 depicts primary and secondary level of learners are most victim of this coronavirus pandemic. Also, the ministry of higher education postponed the Higher Secondary school certificate examination for a longer time. It also seriously hampered the number of students who wish to go abroad for higher studies. UNESCO is supporting nations in their endeavors to alleviate the quick effect of school terminations, especially for increasingly powerless and impeded networks, and to encourage the progression of training for all through remote learning. By this time the Government of Bangladesh announced to continue the classes at all levels through a digital platform and allocate a special fund.

Banking and Financial Service: Money related division, explicitly the financial area in Bangladesh, can be the most influenced segment. This is on the grounds that banks were the core of all emergencies, for example, the sovereign euro emergency and the worldwide money related emergency. In the event that banks come up short, the Small and Medium Enterprises (SMEs) will be progressively influenced. According to Barua S. (2020) banks globally could face increased credit and default risk since business generate cash insufficient to service debt due to business closures, shut-downs, and lower demand for goods and services during both the pandemic and post-pandemic periods. He also added that many lending or investment decisions being postponed for now may not see light again. While Federal Reserve has already reduced the policy rate to increase liquidity to tackle the impacts, the measure has created increased concern for the health of financial. The World Bank predict that such financial impact of coronavirus will mitigate about 24 million people from escaping poverty in East-Asia and the Pacific alone [Vaswani, K. (2020), https://www.bbc.com/news/business-52103666]. The remittance effect could be huge for developing countries that are major exporters of migrant labor and rely on their foreign remittances earned like India and Bangladesh as loss of jobs and delayed or non-payment of wages in different countries might significantly reduce remittance inflows putting extra pressure on their reserve and currency markets [Barua S. (2020)]. 10 million Bangladeshis working abroad such as Saudi Arabia, Italy, United States sent about USD \$18 billion in FY 2018-19. Figure 6 depicts remittances in Bangladesh decreased to 1638.53 USD 
million in January from 1691.68 USD million in December of 2019 [trading economics, https://tradingeconomics.com/bangladesh/remittances].

Figure 6: Remittances earned by Bangladesh in 2019-2020

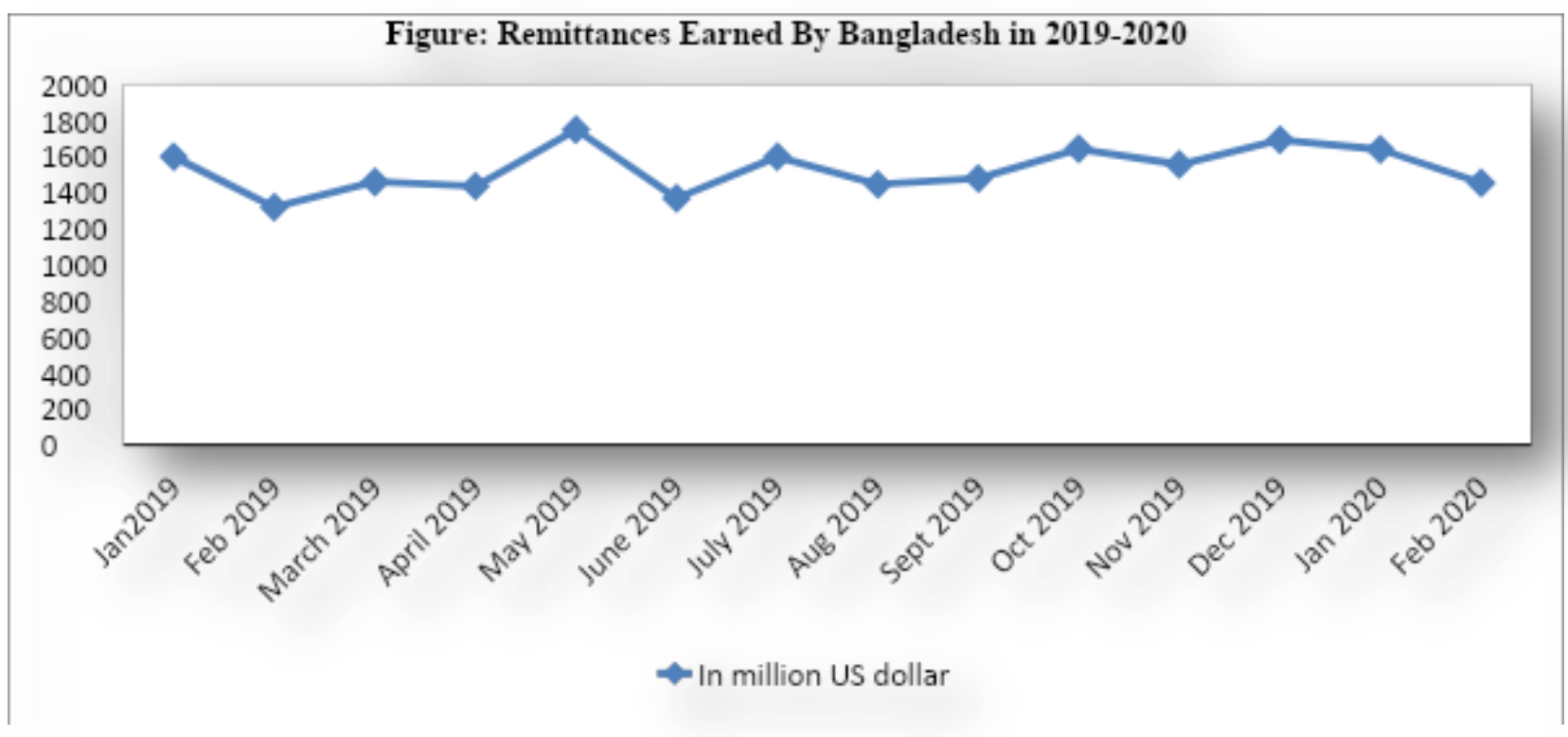

Source: Author, Based on the Data from Bangladesh Bank-2020

Major currencies such as GBP, Yuan, Euro, and Yen all weakened against US Depreciations could be driven by the decline in trade flows and fewer international transactions, as the pandemic goes worldwide [Barua S. (2020)]. Financial exchange additionally free fall around USD \$5.22 billion a week ago of March, compelling the Bangladesh Securities and Exchange Commission to establish an electrical switch to control the slide - stopping exchanging if costs fell beneath a specific level.

Tourism and Travel Agency: Tourism and hospitality industry is adversely affected by the pandemic. Tounta P.(2020) summarized the coronavirus outbreak affecting the global tourism and hotel business due to travel restrictions, fear of illness abroad, fear of using airports and other centers of mass gatherings etc. [Tounta P.(2020)]. Similarly, travel agencies constitute a fragmented sector in Bangladesh, and owing to COVID-19, many small ones are expected to close shop. Airlines and hotels have also been badly hit. However Tourism and Hotel Business in Bangladesh will be affected by the pandemic. Lower tourist spending will affect not only hotels, restaurants, taxi enterprises, and tourist guides, but also food processing and agriculture. 
According to The Asian Development Bank (ADB) (2020) revenue from tourism will decline by $0.001 \%$ in the best-case scenario, $0.002 \%$ in the moderate case scenario and $0.003 \%$ in the worst-case scenario [ADP (2020)].

Conclusion: As pandemic just spread in Bangladesh the end of this pandemic is uncertain. In this situation recovery from disease is the main concern rather than considering the economic impact. Overall, the current economic situation may seriously undermine the livelihood of the underprivileged cohort of the population. Lack of access to basic healthcare, knowledge of hygiene and social safety net has always been a challenge for this cohort and the pandemic is likely to increase these challenges, exponentially. The issues that need to be emphasized in the development of agriculture and the benefit of the farmer are the expansion of the sale of rice and flour to the upazila stage at the fixed rates by the government in the open market so that ultraprofit traders can't syndicate and raise unnecessary prices. Keeping an eye on our current most trusted crop, so that there is no shortage of irrigation in Boro rice; Keep an eye on crops in the Haor area so as not to be affected by heavy rains or floods in advance; to increase the supply of agricultural commodities such as fertilizers, fuel oils, pesticides, herbs and other seeds; to give advance instructions to the farmers about the crops to be harvested next season; reduce the cost of irrigation and agricultural equipment; Curing disease of crops; The farmers should be particularly mindful of the fair value of their produce (grain, vegetables, fish, meat, eggs, milk); keeping a watchful eye on raising subsidies in agriculture. The government should encourage pharmaceutical players to invest in their research and development processes to increase their capacity to ramp up production of possible vaccines as soon as possible. Last but not least, those patients in coronas are not deprived of healthcare.

\section{References:}

1. WHOa. (World Health Organization): Coronavirus disease (COVID-2019) situation reports.2020.https://www.who.int/emergencies/diseases/novel-coronavirus2019/situationreports/. Retrieved 09 March 2020. 2020.

2. Uddin, M. B., Hasan, M., Rashid, A.H.A., Ahsan, M. I., Imran, M. A. S.,. Ahmed. S. S., U.(2020). Novel Coronavirus (COVID-19): Molecular Evolutionary Analysis, Global Burden and Possible Threat to Bangladesh. Nature Research. *(preprint) 
3. WHOb. Statement on the second meeting of the International Health Regulations (2005) Emergency Committee regarding the outbreak of novel coronavirus (2019-nCoV)". World Health Organization. 30 January 2020. Archived from the original on 31 January 2020. Retrieved 30 January 20.

4. "WHOc-General's opening remarks at the media briefing on COVID-19-11 March 2020". World Health Organization. 11 March 2020. Retrieved 11 March2020.

5. CDCa (Centers for Disease Control and Prevention), Coronavirus Disease 2019 (COVID19)_-Transmission". Centers for Disease Control and Prevention. 17 March 2020. Retrieved 23 March 2020.

6. WHOd"Q\&A on coronaviruses". World Health Organization. 11 February 2020. Retrieved 24 February 2020.

7. European Centre for Disease Prevention and Control. "Q \& A on COVID-19". Retrieved 23 March 2020.

8. "Coronavirus Update (Live) - Worldometer". www.worldometers.info.

9. CSSE (Center for Systems Science and Engineering at Johns Hopkins University) ,Coronavirus COVID-19 Global Cases ". ArcGIS. Johns Hopkins CSSE. Retrieved 4 April 2020

10. $\mathrm{CDCb}$ (Centers for Disease Control and Prevention) (3 February 2020). "Coronavirus Disease 2019 (COVID-19): Prevention \& Treatment". Archived from the original on 15 December 2019. Retrieved 10 February 2020.

11. WHOe, "Advice for Public". Archived from the original on 26 January 2020. Retrieved 10 February 2020.

12. IEDCR,(2020). Research Institute of Epidemiology, Disease Control and. "করোনাইনফো". corona.gov.bd. Retrieved 27 March 2020.

13. Dhaka Tribune.(2020) "Coronavirus: Bangladesh declares public holiday from March 26 to April 4". 23 March 2020. Retrieved 27 March 2020.

14. Chen, L., \& Hong, J. (2020). Coronavirus hits China's workers as businesses say they can't pay wages now. Fortune. Accessed 31 March 2020, from https://fortune.com/2020/02/19/coronavirus-china-workers-businesses-pay-wages/

15. Barua, S.(2020). Understanding Coronanomics: The economic implications of the coronavirus (COVID-19) pandemic,

16. Baldwin, R. and di Mauro, B.W. (eds). (2020). Economics in the Time of COVID-19. A VoxEU.org Book, Centre for Economic Policy Research, London. Accessed 26 March 2020 at: https://voxeu.org/system/files/epublication/COVID-19.pdf

17. di Mauro, B.W. (2020). Macroeconomics of the flu. In Baldwin, R. and di Mauro, B.W. (eds). (2020). Economics in the Time of COVID-19. A VoxEU.org Book, Centre for Economic Policy Research, London. Accessed 26 March 2020 at: https://voxeu.org/system/files/epublication/COVID-19.pdf

18. Qiu, W., Chu, C. Mao, A. and Wu, J.(2018). The Impacts on Health, Society, and Economy of SARS and H7N9 Outbreaks in China: A Case Comparison Study. Journal of 
Environmental and Public Health, Volume 2018, Article ID 2710185, 7 pages, https://doi.org/10.1155/2018/2710185.

19. UNESCO, https://en.unesco.org/

20. Wilson, A. (2020). Coronavirus travel updates: which countries have restrictions and FCO warnings in place? The Guardian. Accessed 31 March 2020, from https://www.theguardian.com/travel/2020/mar/24/coronavirus-travel-updates-whichcountries-have-restrictions-and-fco-warnings-in-place Electronic

21. Whalen, J., \&Bhattarai, A. (2020). U.S. companies face crucial test over China's factory shutdown. Washington Post. Accessed 31 March 2020, from https://www.washingtonpost.com/business/2020/02/25/us-companies-so-far-are-

surviving-chinas-factory-shutdown-next-few-weeks-are-crucial/

22. Choudhury S. R. (2020). The coronavirus outbreak is crushing Bangladesh's garment export with growing order cancellations. PUBLISHED FRI, MAR 27 20204:22 AM EDT https://www.cnbc.com/2020/03/27/coronavirus-bangladesh-garment-sector-facesgrowing-order-cancellations.html

23. Jha D. K. \&Narasimhan. T. E.(2020). Cotton, yarn prices fall as coronavirus brings exports to China to halt. Business Stanadrd. Last Updated at March 6, 2020 01:10 IS, https://www.business-standard.com/article/markets/cotton-yarn-prices-fall-ascoronavirusbrings-exports-to-china-to-a-halt-120030501444_1.html

24. Nazrul, S.(2020). Bangladesh Pharmaceutical Sector Wading through the Pandemic, LIGHTCASTLE ANALYTICS WING, March 30, 2020, 7:45 pm, https://www.lightcastlebd.com/insights/2020/03/30/bangladesh-pharmaceutical-sectorwading-through-the-pandemic

25. Gatiso TT, Ordaz-Ne 'meth I, Grimes T, Lormie M, Tweh C, Ku "hl HS, et al. (2018) The impact of the Ebola virus disease (EVD)epidemic on agricultural production and livelihoods in Liberia. PLoSNegl Trop Dis 12(8): e0006580. https://doi.org/10.1371/journal.pntd.0006580.

26. Roy R. (2020), Mitigating Covid-19 impacts on food and agriculture, Published: April 03, $2020 \quad 22: 44: 24 \quad$ Updated: April 04, 2020 22:12:34https://thefinancialexpress.com.bd/views/mitigating-covid-19-impacts-on-foodand-agriculture-1585932264

27. The Business Standard, Poultry sector stares at over Tk1,150 crore losses, 31 March, 2020, 09:35 pm, Last modified: 01 April, 2020, 10:19 am, https://tbsnews.net/economy/industry/poultry-sector-stares-over-tk1150-crore-losses $\underline{63472}$

28. Parke, C. (2020). "Churches cancel Sunday service, move online amid coronavirus pandemic". Fox News. Archived from the original on 15 March 2020. Retrieved 16 March 2020. https://www.foxnews.com/us/coronavirus-update-church-sunday-serviceonline

29. Rafee A. A.(2020), The COVID-19 Outbreak: How Has Bangladesh Fared? STMSON, March 31, 2020, https://www.stimson.org/2020/the-covid-19-outbreak-how-hasbangladesh-fared/ 
30. Irani, B., (2020). Hand sanitizer, mask prices skyrocketing,DhakaTribune, Published at 10:48 pm March 9th, 2020, https://www.dhakatribune.com/business/2020/03/09/handsanitizer-mask-prices-skyrocketing

31. Vaswani, K. (2020, March 31). Coronavirus: Millions will be left in poverty, World Bank warns. BBCNEWS Business. Accessed 31 March 2020 at: https://www.bbc.com/news/business-52103666

32. TRADING ECONOMICS, Bangladesh Remittances, 2012-2020 Data | 2021-2022 Forecast, https://tradingeconomics.com/bangladesh/remittances

33. Tounta, P. (3 March 2020). "Pandemic 2020: The impact on tourism and the shadowy points". TravelDailyNews International. TravelDailynews Media Network. Retrieved 31 March 2020. https://www.traveldailynews.com/post/pandemic-2020-the-impact-ontourism-and-the-shadowy-points

34. ADP (Asian Development Bank) (2020), Coronavirus stands to wipe $\$ 3 \mathrm{~b}$ off Bangladesh economy,Finds an ADB analysis; 2:00 AM, March 08, 2020 / LAST MODIFIED: 12:12 PM, March 08, 2020; https://www.thedailystar.net/business/news/coronavirus-standswipe-3b-bangladesh-economy-1877950

35. Adhikari S. P., , Meng, S., Wu, Y., Mao, Y., Ye, R., Wang, Q., Sun, C., Sylvia,S., Scott Rozelle,S., Raat, H., and Zhou, H. (2020) Epidemiology, causes, clinical manifestation and diagnosis, prevention and control of coronavirus disease (COVID-19) during the early outbreak period: a scoping review, Infectious Diseases of Poverty, 9:29

36. LIGHTCASTLE ANALYTICS WING,(2020), The Effect of COVID-19 on Bangladesh's $\begin{array}{llll}\text { Apparel Industry,March } & 29, & 2020, & 7: 57\end{array}$ pm,https://www.lightcastlebd.com/insights/2020/03/29/the-effect-of-covid-19-onbangladeshs-apparel-industry

37. BER (2019). Bangladesh Economic Review, Dhaka, Bangladesh.

38. "Covid-19 pandemic: Testing remains low despite having enough kits in stock". Dhaka Tribune. 29 March 2020. Retrieved 30 March 2020.

39. "Massive Bangladesh coronavirus prayer gathering sparks outcry". news.yahoo.com. Retrieved 30 March 2020.

40. "Six die with coronavirus symptoms, no new case reported in Bangladesh". New Age | The Most Popular Outspoken English Daily in Bangladesh. Retrieved 30 March 2020.

41. MOE (2020). Ministry of Education, Dhaka, Bangladesh. 